\title{
IMPLEMENTASI MODEL PROBLEM BASED LEARNING DALAM MENINGKATKAN PRESTASI DAN KEAKTIFAN BELAJAR PENDIDIKAN AGAMA ISLAM POKOK BAHASAN IBADAH SALAT
}

\author{
Istiqomah \\ SDN 020 Tanjung Selor, Tanjung, Bulungan Kalimantan Utara \\ dindaisti12@gmail.com
}

\begin{abstract}
ABSTRAK
Penelitian ini bertujuan untuk mengetahui apakah ada peningkatan prestasi belajar Pendidikan Agama Islam (PAI) siswa kelas IV di SDN 020 Tanjung Selor, Tahun Pelajaran 2017/2018. Subjek penelitian tindakan kelas ini adalah siswa kelas IV SDN 020 Tanjung Selor. Variabel penelitian ini terdiri atas variabel siswa berupa kemampuan dalam menyelesaikan soal dan variabel guru berupa rencana pembelajaran dan pelaksanaannya di dalam kelas. Penelitian dilakukan dalam dua siklus yang masing-masing terdiri atas empat tahapan, yakni: perencanaan, pelaksanaan, observasi dan refleksi. Indikator keberhasilan ditetapkan bila minimal terdapat $75 \%$ siswa mencapai ketuntasan belajar setelah diterapkan Model Problem Based Learning (PBL). Dari hasil penelitian diperoleh temuan bahwa ada peningkatan prestasi belajar Pendidikan Agama Islam siswa kelas IV SDN 020 Tanjung Selor yang ditunjukkan dengan: (1) rata-rata prestasi belajar siswa pada siklus I adalah 6,74 dan pada siklus II adalah 8,64; (2) ketuntasan belajar siswa pada siklus I siswa 9 siswa atau 45,00\% dan yang tidak tuntas sebanyak 11 siswa atau 55,00\%; serta (3) ketuntasan belajar klasikal pada siklus I adalah 45,00\% dan pada siklus II mencapai 100,00\%. Uji kompetensi siklus II lebih baik dibandingkan siklus I dan sudah mencapai indikator ketuntasan. Disamping itu terdapat peningkatan aktivitas siswa baik individu maupun kelompok. Temuan lain menunjukkan bahwa respon siswa terhadap pelaksanaan Model Problem Based Learning (PBL) mencapai 82, 50\% menyatakan sangat setuju atau dalam kategori tinggi.

Kata Kunci: PBL, Prestasi, Keaktifan, PAI
\end{abstract}

\section{ABSTRACT}

This study aims to find out whether there is an increase in the learning achievement of Islamic Education (PAI) grade IV students at SDN 020 Tanjung Selor, Academic Year 2017/2018. The subjects of this class action 
research are students of grade IV SDN 020 Tanjung Selor. This research variable consists of student variables in the form of the ability to solve problems and teacher variables in the form of learning plans and their implementation in the classroom. The study was conducted in two cycles, each of which consisted of four stages: planning, implementing, observing, and reflecting. Indicators of success are determined when there are at least $75 \%$ of students achieving mastery learning after applying the Problem Based Learning (PBL) Model. From the results of the study, it was found that there was an increase in the learning achievement of Islamic Education students in grade IV SDN 020 Tanjung Selor as indicated by (1) the average student achievement in cycle I was 6.74 and in cycle II it was 8.64; (2) completeness of student learning in cycle I students 9 students or $45.00 \%$ and 11 students or $55.00 \%$ incomplete; and (3) completeness of classical learning in cycle I was $45.00 \%$ and in cycle II it reached $100.00 \%$. The second cycle competency test is better than the first cycle and has reached the completeness indicator. Besides that, there is an increase in student activity both individually and groups. Other findings show that students' responses to the implementation of the Problem Based Learning (PBL) model reached $82,50 \%$ expressed strongly agree or in the high category.

Keywords: PBL, achievement, activeness, Islamic Education.

\section{PENDAHULUAN}

Pendidikan pada dasarnya merupakan seperangkat rencana untuk membentuk peserta didik menjadi insan mulia yang mengembangkan potensi dalam dirinya sehingga menjadi insan yang memiliki keseimbangan dalam segala bidang, yaitu spiritual, sosial, pengetahuan dan keterampilan, kecerdasan, kepribadian, akhlak mulia, yang semua hal tersebut diperlukan dalam kehidupan sehari-hari di masyarakat, bangsa dan negara. Undang-Undang Nomor 20 Tahun 2003: 10 tentang Sitem Pendidikan Nasional Pasal 37, yaitu: Kurikulum pendidikan dasar dan menengah wajib memuat: (a) pen-didikan agama; (b) pendidikan kewarganegaraan; (c) bahasa; (d) matematika; (e) ilmu pengetahuan alam; (f) ilmu pengetahuan sosial; (g) seni dan budaya; (h) pendidikan jasmani dan olahraga; (i) keterampilan/kejuruan; dan (j) muatan lokal.

Dalam Peraturan Pemerintah Nomor 55 Tahun 2007 tentang Pendidikan Agama dan Pendidikan Keagamaan Pasal 1 disebutkah bahwa pendidikan agama adalah pendidikan yang memberikan pengetahuan dan membentuk sikap, kepribadian, dan ketrampilan peserta didik dalam mengamalkan ajaran agamanya, 
yang dilaksanakan sekurang-kurangnya melalui mata pelajaran/kuliah pada semua jalur, jenjang, dan jenis pendidikan.

Penguasaan keterampilan peserta didik dalam mengamalkan ajaran agamanya yakni ibadah salat adalah suatu keterampilan mutlak/ harus dimiliki oleh siswa beragama Islam. Keterampilan pokok bahasan ibadah salat yang baik dapat membawa siswa mampu menyelesaikan soal-soal yang mengandung ibadah salat dan kefasihan dalam melaksanakan ibadah salat sehari semalam 5 waktu (17 Rakaat). Bila kemampuan dalam penguasaan keterampilan salat (dalam hal ini) kefasihan salat yang melibatkan berbagai macam seperti rukun salat, syarat wajib salat, syarat sah salat, sunnah-sunnah salat dan hal-hal yang membatalkan salat dengan baik dan benar, tentu akan sangat membantu baik bagi guru PAI maupun siswa sendiri dalam belajar maupun melaksanakan ibadah salat.

Kenyataan yang terjadi di kelas IV SDN 020 Tanjung Selor adalah penguasaan keterampilan ibadah salat kurang baik, sehingga menyebabkan guru terhambat dalam pembelajaran rukun salat, syarat wajib salat, syarat sah salat, sunnah-sunnah salat dan hal-hal yang membatalkan salat yang harus mereka kuasai. Kenyataan ini tampak pada hasil-hasil analisis ulangan harian yang dilakukan oleh peneliti (guru PAI), di mana kebanyakan soal tidak sempurna dijawab oleh siswa adalah soal-soal yang melibatkan ibadah salat.

Kemungkinan penyebab permasalahan ini adalah: (1) kurangnya latihan/tugas yang tersusun dengan urutan yang baik (logis). (2) pemberdayaan pemecahan masalah belum optimal (3) pengetahuan tentang salat masih sangat minim. (4) siswa mayoritas berada pada lingkungan yang kurang mendukung. (5) anak didik kurang tertarik dalam mengikuti proses pembelajaran yang menerangkan pokok bahasan tentang salat. (6) guru belum memfasilitasi pembelajaran untuk memecahkan masalah. (7) guru belum mengembangkan kegiatan diskusi kelompok. (8) guru belum memanfaatkan media secara maksimal. (9) guru kurang maksimal menggunakan media pembelajaran yang dapat dilihat dan didengar serta menarik siswa, sehingga siswa dalam belajar (1) kurang terlibat aktif , kurang antusias, malu mengungkapkan pendapatnya. (2) belum memiliki kemampuan memecahkan masalah dalam situasi nyata, sehingga hasil belajar siswa 63,64 siswa tidak mencapai KKM dalam pembelajaran PAI

Penyebab lain adalah metode atau model yang diterapkan oleh guru cenderung statis dan membosankan, sehingga anak didik kurang tertarik untuk mengikuti 
pelajaran. Penerapan metode maupun model yang tepat sangat mempengaruhi keberhasilan proses belajar mengajar. Sebaliknya, kesalahan dalam menerapkan metode atau model akan berakibat fatal. Selama ini, metodologi pembelajaran Pendidikan Agama Islam yang diterapkan masih mempertahankan cara-cara lama (tradisional/ ekspositori) seperti ceramah, menghafal dan demonstrasi praktik-praktik ibadah yang tampak kering, pola pengajaran yang dikembangkan oleh guru, siswa terjebak menjadi obyek pembelajar yang pasif dan hanya menunggu dari guru baik untuk mencatat maupun menghafal pokok bahasan yang diajarkan. Cara-cara seperti itu diakui atau tidak membuat siswa tampak bosan, jenuh dan kurang bersemangat dalam belajar Agama Islam. Untuk itu, perlu adanya penerapan model pembelajaran yang baru, dengan harapan mampu menimbulkan daya tarik pada siswa dalam proses belajar mengajar. Untuk mengatasi permasalahan yang telah penulis paparkan, penulis memutuskan untuk menggunakan model pembelajaran berbasis masalah atau model Problem Based Learning (PBL) dalam pelajaran PAI khususnya dalam pokok bahasan ibadah salat. Hal ini selaras dengan Neo \& Megan (2002: 3) yang menyatakan bahwa pembelajaran berbasis masalah akan sangat memotivasi para pelajar baik pribadi maupun dalam kelompok untuk menyelesaikan permasalahan sebagai bentuk dari pemahaman mereka. Amir (2009: 11) menambahkan bahwa pembelajaran berbasis masalah dapat membantu cara berpikir siswa menjadi semakin kritis.

Melihat fenomena yang terjadi di SDN 020 Tanjung Selor tersebut, maka penelitian ini bertujuan untuk mengetahui apakah ada peningkatan prestasi dan keaktifan belajar Pendidikan Agama Islam (PAI) siswa kelas IV di SDN 020 Tanjung Selor dengan Menerapkan Model Problem Based Learning Tahun Pelajaran 2017/2018.

\section{METODE PENELITIAN}

Penelitian ini termasuk penelitian lapangan (Field Research) yang dilakukan di suatu tempat atau lokasi yang dipilih untuk meneliti atau menyelidiki sesuatu yang terjadi di tempat tersebut (Fathoni, 2006: 96). Pendekatan penelitian ini menggunakan pendekatan kualitatif dengan jenis penelitian deskriptif yaitu dengan menyajikan analisis mengenai penerapan model Problem Based Learning dalam meningkatkan prestasi dan keaktifan belajar Pendidikan Agama Islam pokok bahasan "Ibadah Salat" siswa kelas IV SDN 020 Tanjung Selor Bulungan Kalimantan Utara Tahun ajaran 
2017/2018 secara rinci dan akurat melalui hasil data deskriptif yang berasal dari data tertulis dan wawancara lisan dari orang-orang terkait. Data penelitian berupa data kualitatif yang berbentuk kata, kalimat, gerak tubuh, ekspresi wajah, bagan, gambar, dan foto yang berkaitan dengan pembelajaran dalam implementasi metode problem based learning (Fathoni, 2006: 96).

Subjek penelitian tindakan kelas ini adalah siswa kelas IV SDN 020 Tanjung Selor. Variabel penelitian ini terdiri atas variabel siswa berupa kemampuan dalam menyelesaikan soal dan variabel guru berupa rencana pembelajaran dan pelaksanaannya di dalam kelas. Penelitian dilakukan dalam dua siklus yang masingmasing terdiri atas empat tahapan, yakni: perencanaan, pelaksanaan, observasi dan refleksi. Indikator keberhasilan ditetapkan bila minimal terdapat $75 \%$ siswa mencapai ketuntasan belajar setelah diterapkan Model Problem Based Learning (PBL). Penelitian ini menggunakan ruang kelas sebagai tempat penelitian. Waktu dalam penelitian dilakukan selama tiga bulan.

Teknik pengumpulan data menggunakan studi dokumentasi dan wawancara dengan melihat atau menganalisis dokumen-dokumen yang dibuat oleh subjek sendiri atau oleh orang lain (Sugiyono, 2017). Analisis data penelitian mengunakan analisis data kualitatif dengan cara deduksi yaitu proses pendekatan yang berangkat dari kebenaran umum mengenai suatu fenomena (teori) dan menggeneralisasikan kebenaran tersebut pada suatu peristiwa atau data tertentu yang berciri sama dengan fenomena yang bersangkutan (prediksi) (Azwar, 2010: 40).

Langkah-langkah dan rancangan yang digunakan untuk mengukur potensi keaktifan siswa dalam kerja secara individu maupun kelompok, peneliti/guru selama penerapan model Problem Based Learning (PBL) berlangsung, data prestasi siswa ini ditunjukkan pada gambar berikut:

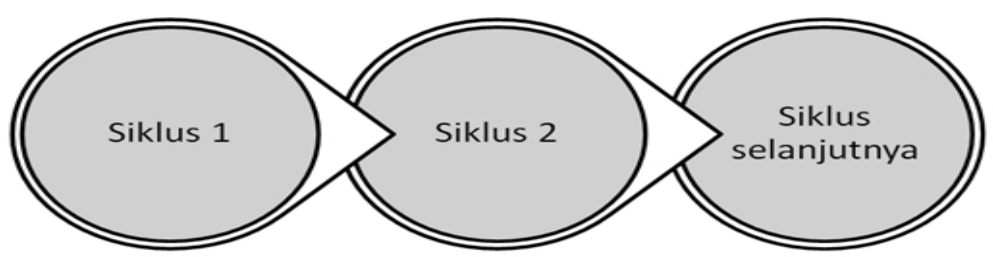

Gambar 1 Siklus langkah dan rancangan

Gambar 1 Siklus langkah dan rancangan

- Permasalahan awal

- Perencanaan

- Pelaksanaan
- Permasalahan siklus 1

- Perencanaan

- Pelaksanaan 
56 | Tarbawi : Jurnal Pendidikan Islam Vol. 17. No. 2. Juli - Desember 2020

- Pengamatan

- Refleksi
- Pengamatan

- Refleksi

\section{PEMBAHASAN}

Penelitian ini dirancang dalam beberapa siklus, masing-masing siklus terdiri atas empat tahap yaitu perencanaan, tindakan, pengamatan dan refleksi. Apabila sudah mencapai hasil yang diharapkan, maka siklus dianggap cukup. Pembahasan hasil penelitian tiap siklus adalah sebagai berikut:

a. Siklus a

Tabel 1 Keaktifan siswa secara individu siklus I

\begin{tabular}{|c|c|c|c|c|}
\hline \multirow[t]{2}{*}{ NO } & \multirow[t]{2}{*}{ Keaktifan siswa } & \multicolumn{3}{|c|}{$\begin{array}{c}\text { Skor } \\
\text { pengamatan }\end{array}$} \\
\hline & & 1 & 2 & 3 \\
\hline 1 & Kehadiran siswa dalam mengikuti pelajaran & & & 3 \\
\hline 2 & $\begin{array}{l}\text { Siswa memperhatikan saat guru menjeaskan pokok } \\
\text { bahasan pelajaran }\end{array}$ & & 2 & \\
\hline 3 & Keaktifan siswa dalam mengikti pelajaran & & 2 & \\
\hline 4 & Kemampuan siswa dalam mengerjakan soal & & 2 & \\
\hline 5 & Kemampuan siswa dalam menanggapi masalah & & 2 & \\
\hline 6 & Siswa menyelesaikan soal menggunakan lembar kerja & 1 & & \\
\hline 7 & $\begin{array}{l}\text { Siswa berinteraksi satu sama lain (misalnya } \\
\text { bertanya,diskusi,dll. }\end{array}$ & 1 & & \\
\hline 8 & $\begin{array}{l}\text { Siswa berani bertanya kepada guru apabila menemui } \\
\text { kesulitan }\end{array}$ & & 2 & \\
\hline 9 & Semangat siswa dalam belajar & & 2 & \\
\hline \multirow[t]{6}{*}{10} & Ketenangan kelas & & 2 & \\
\hline & Jumlah & 3 & 12 & 3 \\
\hline & Total Skor & \multicolumn{3}{|c|}{18} \\
\hline & Skor Maksimal & \multicolumn{3}{|c|}{30} \\
\hline & Prosentase Skor (\%) & \multicolumn{3}{|c|}{$60.00 \%$} \\
\hline & Kriteria Penafsiran & \multicolumn{3}{|c|}{ Rendah } \\
\hline
\end{tabular}

Penilaian:

1 : Jika banyaknya siswa melakukan aktivitas $<45 \%$

2 : Jika banyaknya siswa melakukan aktivitas $45 \%-75 \%$

3 : Jika banyaknya siswa melakukan aktivitas $>75 \%$

Kriteria penafsiran :

$$
\begin{array}{ll}
>75 \% & =\text { Keaktifan tinggi } \\
65 \%-75 \% & =\text { Keaktifan sedang } \\
<65 \% & =\text { Keaktifan rendah }
\end{array}
$$


Tabel 2 Pengamatan terhadap siswa secara Kelompok Siklus 1

\begin{tabular}{|c|c|c|c|c|c|c|c|c|c|c|c|c|c|c|c|c|c|c|c|c|c|c|c|c|}
\hline \multirow{2}{*}{ Kel. } & \multirow{2}{*}{ No } & \multirow{2}{*}{ Nama Siswa } & \multicolumn{4}{|c|}{$A$} & \multicolumn{4}{|c|}{$B$} & \multicolumn{3}{|c|}{ C } & \multicolumn{3}{|c|}{$D$} & \multicolumn{2}{|c|}{$E$} & \multirow{2}{*}{ Jml } & \multirow{2}{*}{\begin{tabular}{|l|} 
Skor \\
Maks
\end{tabular}} & \multirow{2}{*}{ Skor } & \multirow{2}{*}{\begin{tabular}{|l|} 
Skor \\
Kel
\end{tabular}} & \multirow{2}{*}{$\%$} & \multirow{2}{*}{ Ket } \\
\hline & & & 1 & \begin{tabular}{|l|}
2 \\
\end{tabular} & 3 & 4 & 1 & \begin{tabular}{|l|l}
2 & \\
\end{tabular} & 3 & 4 & 1 & \begin{tabular}{l|l}
2 & 3 \\
\end{tabular} & 4 & 1 & \begin{tabular}{|l|l|}
2 & 3 \\
\end{tabular} & 4 & \begin{tabular}{l|l|}
1 & 2 \\
\end{tabular} & \begin{tabular}{l|l}
3 & 4 \\
\end{tabular} & & & & & & \\
\hline \multirow{6}{*}{1} & 1 & Sandi & & & 3 & & & 2 & & & & 2 & & & 3 & & & 3 & 13 & 20 & 6.50 & \multirow{6}{*}{6.00} & $65 \%$ & Baik \\
\hline & 2 & Ahmad Dani & & 2 & & & & 2 & & & & 3 & & & 3 & & & 4 & 14 & 20 & 7.00 & & $70 \%$ & Baik \\
\hline & 3 & Haikal & & & 3 & & & 2 & & & & 2 & & & 2 & & 2 & & 11 & 20 & \begin{tabular}{|l|}
5.50 \\
\end{tabular} & & $55 \%$ & Cukup \\
\hline & 4 & Moh. Ghony & & 2 & & & & 2 & & & & 2 & & & 3 & & \begin{tabular}{|l|}
2 \\
\end{tabular} & & 11 & 20 & 5.50 & & $55 \%$ & Cukup \\
\hline & 5 & Ahmad Zidan & & 2 & & & & & 3 & & & 2 & & & 2 & & 2 & & 11 & 20 & 5.50 & & $55 \%$ & Cukup \\
\hline & \multicolumn{2}{|r|}{ Jumlah } & \multicolumn{4}{|c|}{ Jumlah } & \multicolumn{4}{|c|}{11} & \multicolumn{3}{|c|}{11} & \multicolumn{3}{|c|}{13} & & 13 & 60 & 100 & 6.00 & & $60 \%$ & \\
\hline & 1 & Dinda Tri & & 2 & & & & & 3 & & & 2 & & & 3 & & 2 & & 12 & 20 & 6.00 & & $60 \%$ & Baik \\
\hline 2 & 2 & Indira Rahma & & & 3 & & & & 3 & & & 3 & & & 2 & & & 3 & 14 & 20 & 7.00 & & $70 \%$ & Baik \\
\hline & 3 & $\begin{array}{l}\text { Sutan } \\
\text { Nafaras }\end{array}$ & & 2 & & & & 2 & & & & 2 & & & 3 & & & 3 & 12 & 20 & 6.00 & 6.00 & $60 \%$ & Baik \\
\hline & 4 & Doniawan & & 2 & & & & 2 & & & & 2 & & & 2 & & \begin{tabular}{|l|}
2 \\
\end{tabular} & & 10 & 20 & 5.00 & & $50 \%$ & Cukup \\
\hline & 5 & Moh. Kifli & & \begin{tabular}{|l|l|}
2 \\
\end{tabular} & & & & 2 & & & & 3 & & & 3 & & \begin{tabular}{|l|}
2 \\
\end{tabular} & & 12 & 20 & 6.00 & & $60 \%$ & Baik \\
\hline & & Jumlah & & Juml & & & & 12 & & & & 12 & & & 13 & & & 12 & 60 & 100 & 6.00 & & $60 \%$ & \\
\hline & 1 & Moh. Fajiri & & & \begin{tabular}{|l|}
3 \\
\end{tabular} & & & & 3 & & & 3 & & & 2 & & & 3 & 14 & 20 & 7.00 & & $70 \%$ & Baik \\
\hline 3 & 2 & Dika Bayu & & 2 & & & & 2 & & & & 2 & & & 2 & & 2 & & 10 & 20 & 5.00 & & $50 \%$ & Cukup \\
\hline & 3 & Bayu Dian & & 2 & & & & & 3 & & & 2 & & & 2 & & 2 & & 11 & 20 & 5.50 & & $55 \%$ & Cukup \\
\hline & 4 & Puja Juleita & & & \begin{tabular}{|l|l|}
3 \\
\end{tabular} & & & & 3 & & & 3 & & & 3 & & & 3 & 15 & 20 & 7.50 & 6.10 & $75 \%$ & Baik \\
\hline & 5 & Devi Aulia & & 2 & & & & 2 & & & & 3 & & & 2 & & 2 & & 11 & 20 & 5.50 & & $55 \%$ & Cukup \\
\hline & & Jumlah & & Juml & & & & 13 & & & & 13 & & & 11 & & & 12 & 61 & 100 & 6.10 & & $61 \%$ & \\
\hline & 1 & Farel & & 2 & & & & 2 & & & & 2 & & & 2 & & 2 & & 10 & 20 & 5.00 & & $50 \%$ & Cukup \\
\hline 4 & 2 & Habib Jamal & & 2 & & & & & 3 & & & 3 & & & 2 & & 2 & & 12 & 20 & 6.00 & & $60 \%$ & Baik \\
\hline & 3 & Riska Eli & & & 3 & & & & 3 & & & 3 & & & 2 & & 2 & & 13 & 20 & 6.50 & & $65 \%$ & Baik \\
\hline & 4 & Suci Hardianti & & & 3 & & & & 3 & & & 3 & & & 3 & & & 3 & 15 & 20 & 7.50 & 6.20 & $75 \%$ & Baik \\
\hline & 5 & Ririn Wulan & & 2 & & & & & 3 & & & 3 & & & 2 & & 2 & & 12 & 20 & 6.00 & & $60 \%$ & Baik \\
\hline & & Jumlah & & 12 & & & & 14 & & & & 14 & & & 11 & & & 11 & 62 & 100 & 6.20 & & $62 \%$ & \\
\hline & & Total & & 47 & & & & 50 & & & & 50 & & & 48 & & & 48 & 243 & Baik Sel & & & & 0 \\
\hline & & Skor Maksimal & & 80 & & & & 80 & & & & 80 & & & 80 & & & 80 & 400 & Baik & & & & 12 \\
\hline & & $\begin{array}{l}\text { ingkat Aktivitas } \\
\text { (\%) }\end{array}$ & & 599 & & & & $63 \%$ & & & & $63 \%$ & & & $60 \%$ & & & $0 \%$ & $60.75 \%$ & Cukup & & & & 8 \\
\hline & & Kreiteria & & Seda & & & & Sedar & & & & Sedang & & & Sedang & & Sed & dang & Sedang & Skor Ke & Terting & & & 7.50 \\
\hline & & & & $\mathrm{A}$ & & & & $B$ & & & & $C$ & & & $D$ & & & $E$ & & Skor Kel & Terend & dah: & & 5.00 \\
\hline & & & & & & & & & & & & & & & & & & & & Skor Rat & ta-rata : & & & 6.08 \\
\hline
\end{tabular}

Tabel 3 Hasil Keaktifan Siswa secara Kelompok Siklus I

\begin{tabular}{|c|c|l|c|c|c|}
\hline No & \multicolumn{2}{|c|}{ Aktivitas Siswa } & Skor & $\%$ & Ket \\
\hline 1 & A. & Memperhatikan penjelasan guru & 47 & $59 \%$ & Sedang \\
\hline 2 & B. & Kerja sama dalam kelompok & 50 & $63 \%$ & Sedang \\
\hline 3 & C. & Bertanya antar siswa dan guru & 50 & $63 \%$ & Sedang \\
\hline 4 & D. & Keaktifan Menyelesaikan soal & 48 & $60 \%$ & Sedang \\
\hline 5 & E. & Kemampuan presentasi siswa & 48 & $60 \%$ & Sedang \\
\hline
\end{tabular}


Tabel 4 Pengamatan Aktifitas Guru

\begin{tabular}{|c|c|c|c|c|c|}
\hline \multirow{2}{*}{ NO } & \multirow{2}{*}{ Aspek yang dinilai } & \multicolumn{3}{|c|}{ SKOR } & \multirow{2}{*}{ Jml } \\
\hline & & 1 & 2 & 3 & \\
\hline \multirow[t]{4}{*}{1.} & Apersepsi & & & & \\
\hline & a. Menjelaskan tujuan pembelajaran & & & 3 & 3 \\
\hline & $\begin{array}{l}\text { b. Menjelaskan pokok bahasan sesuai dengan model } \\
\text { pembelajaran }\end{array}$ & & 2 & & 2 \\
\hline & $\begin{array}{l}\text { c. Memotivasi siswa mengidentifikasi soal dan } \\
\text { memecahkan masalah }\end{array}$ & 1 & & & 1 \\
\hline \multirow[t]{3}{*}{2} & Mengorganisasikan siswa untuk belajar & & & & \\
\hline & $\begin{array}{l}\text { a. Membimbing siswa mengerjakan tugas dalam } \\
\text { kelompok }\end{array}$ & & 2 & & 2 \\
\hline & b. Membimbing siswa dalam menggunakan lembar kerja & & 2 & & 2 \\
\hline \multirow[t]{3}{*}{3} & Membimbing siswa secara individu atau kelompok & & & & \\
\hline & 1. Melakukan pengamatan tiap kelompok & & 2 & & 2 \\
\hline & 2. Merekam kegiatan siswa & 1 & & & 1 \\
\hline \multirow[t]{5}{*}{4} & Mengembangkan hasil kerja siswa & & & & \\
\hline & a. Membimbing siswa membagi tugas dalam kelompok & & 2 & & 2 \\
\hline & b. Membantu siswa yang mengalami kesulitan & & 2 & & 2 \\
\hline & $\begin{array}{l}\text { c. Membimbing siswa untuk melakukan presentase di } \\
\text { depan kelas }\end{array}$ & 1 & & & 1 \\
\hline & d. Menganalisa dan menyimpulkan & & 2 & & 2 \\
\hline \multirow[t]{7}{*}{5} & Menganalisa dan mengevaluasi pemecahan & & & & \\
\hline & a. Membantu siswa memrikasa hasil kerja sesama siswa & & 2 & & 2 \\
\hline & b. Membantu siswa memeriksa prosedur pekerjaan siswa & 1 & & & 1 \\
\hline & Jumlah skor yang dicapai & \multicolumn{4}{|c|}{23} \\
\hline & Jumlah skor maksimal & \multicolumn{4}{|c|}{39} \\
\hline & Kinerja guru (\%) & \multicolumn{4}{|c|}{$58.97 \%$} \\
\hline & Kriteria & \multicolumn{4}{|c|}{ Cukup } \\
\hline
\end{tabular}

Keterangan :

1 = Kurang

2 = Cukup

$3=$ Baik
Kreteria :

$31-39=$ Pembelajaran baik

$22-30=$ Pembelajaran cukup baik

$13-21=$ Pembelajaran kurang baik 
Sedangkan hasil evaluasi secara individu dapat dilihat pada tabel berikut:

Tabel 5 Hasil Evaluasi Individu Siklus I

\begin{tabular}{|c|c|c|c|c|c|c|c|c|c|c|c|}
\hline \multirow{2}{*}{ No } & \multirow{2}{*}{ Nama Siswa } & \multicolumn{5}{|c|}{ Butir Soal } & \multirow{2}{*}{$\begin{array}{l}\text { Jml } \\
\text { Skor }\end{array}$} & \multirow{2}{*}{$\begin{array}{l}\text { Skor } \\
\text { Maks }\end{array}$} & \multirow{2}{*}{ Nilai } & \multirow{2}{*}{$\%$} & \multirow{2}{*}{ Kriteria } \\
\hline & & 1 & 2 & 3 & 4 & 5 & & & & & \\
\hline 1 & Sandi & 4 & 6 & 3 & 2 & 4 & 19 & 25 & 7.60 & $76.00 \%$ & Tuntas \\
\hline 2 & Ahmad Dani & 4 & 4 & 4 & 2 & 2 & 16 & 25 & 6.40 & $64.00 \%$ & Tidak Tuntas \\
\hline 3 & Haikal & 3 & 6 & 4 & 2 & 4 & 19 & 25 & 7.60 & $76.00 \%$ & Tuntas \\
\hline 4 & Moh. Ghony & 4 & 4 & 3 & 2 & 4 & 17 & 25 & 6.80 & $68.00 \%$ & Tidak Tuntas \\
\hline 5 & Ahmad Zidan & 3 & 6 & 4 & 2 & 4 & 19 & 25 & 7.60 & $76.00 \%$ & Tuntas \\
\hline 6 & Dinda Tri & 3 & 3 & 2 & 2 & 4 & 14 & 25 & 5.60 & $56.00 \%$ & Tidak Tuntas \\
\hline 7 & Indira Rahma & 4 & 4 & 2 & 2 & 2 & 14 & 25 & 5.60 & $56.00 \%$ & Tidak Tuntas \\
\hline 8 & Sutan Nafaras & 3 & 6 & 4 & 2 & 4 & 19 & 25 & 7.60 & $76.00 \%$ & Tuntas \\
\hline 9 & Doniawan & 3 & 5 & 4 & 2 & 3 & 17 & 25 & 6.80 & $68.00 \%$ & Tidak Tuntas \\
\hline 10 & Moh. Kifli & 4 & 6 & 3 & 2 & 4 & 19 & 25 & 7.60 & $76.00 \%$ & Tuntas \\
\hline 11 & Moh. Fajri & 3 & 5 & 4 & 2 & 4 & 18 & 25 & 7.20 & $72.00 \%$ & Tidak Tuntas \\
\hline 12 & Dika Bayu & 3 & 6 & 4 & 2 & 4 & 19 & 25 & 7.60 & $76.00 \%$ & Tuntas \\
\hline 13 & Bayu Dian & 5 & 5 & 4 & 2 & 3 & 19 & 25 & 7.60 & $76.00 \%$ & Tuntas \\
\hline 14 & Puja Juleita & 3 & 4 & 3 & 2 & 2 & 14 & 25 & 5.60 & $56.00 \%$ & Tidak Tuntas \\
\hline 15 & Devi Aulia & 3 & 2 & 3 & 2 & 3 & 13 & 25 & 5.20 & $52.00 \%$ & Tidak Tuntas \\
\hline 16 & Farel & 4 & 6 & 3 & 2 & 4 & 19 & 25 & 7.60 & $76.00 \%$ & Tuntas \\
\hline 17 & Habib Jamal & 5 & 5 & 3 & 2 & 4 & 19 & 25 & 7.60 & $76.00 \%$ & Tuntas \\
\hline 18 & Riska Eli & 3 & 5 & 3 & 2 & 2 & 15 & 25 & 6.00 & $60.00 \%$ & Tidak Tuntas \\
\hline 19 & Suci Hardianti & 2 & 7 & 4 & 2 & 2 & 17 & 25 & 6.80 & $68.00 \%$ & Tidak Tuntas \\
\hline 20 & Ririn Wulan & 2 & 3 & 2 & 2 & 2 & 11 & 25 & 4.40 & $44.00 \%$ & Tidak Tuntas \\
\hline Jumlah & & 68 & 98 & 66 & 40 & 65 & 337 & 500 & 6.74 & $67.40 \%$ & Tidak Tuntas \\
\hline \multicolumn{9}{|c|}{ Rata-rata } & 6.74 & $67.40 \%$ & \\
\hline \multicolumn{9}{|c|}{ Nilai Tertinggi } & 7.60 & & \\
\hline \multicolumn{9}{|c|}{ Nilai Terrendah } & 4.40 & & \\
\hline \multicolumn{9}{|c|}{ Jumlah siswa yang tuntas } & 9 & $45 \%$ & \\
\hline \multicolumn{9}{|c|}{ Jumlah siswa yang tidak tuntas } & 11 & $55 \%$ & \\
\hline \multicolumn{9}{|c|}{ Ketuntasan Klasikal } & $45.00 \%$ & $\begin{array}{l}\text { (Tidak } \\
\text { Tuntas) }\end{array}$ & \\
\hline
\end{tabular}

Setelah melakukan pengamatan atas tindakan pembelajaran, selanjutnya diadakan refleksi dari tindakan yang telah dilaksanakan. Dalam kegiatan pada siklus I didapat hasil refleksi sebagai berikut:

1) Pada saat diskusi observer memantau kerja masing-masing kelompok, tapi masih kurang maksimal dan bimbingan yang dilaksanakan guru terhadap kelompok masih belum merata, sehingga beberapa kelompok tidak dapat menyelesaikan soal dengan baik. Bimbingan individu juga kurang diperhatikan, sehingga ada siswa yang tidak terlibat dalam penyelesaian soal. Jika dilakukan lebih maksimal maka guru akan mengetahui karakteristik dan kelemahan siswa, sehingga siswa dapat memahami pokok bahasan pembelajaran saat itu. 
2) Peneliti/guru dalam menumbuhkan motivasi belajar siswa dalam proses model Problem Based Learning masih kurang optimal.

3) Perhatian siswa terhadap penjelasan guru masih rendah.

4) Dalam mengerjakan soal siswa masih kurang aktif.

5) Pada waktu kerja kelompok siswa kurang mampu berinteraksi dengan siswa yang lain.

6) Siswa masih enggan untuk melakukan presentasi. Siswa masih saling menuding untuk melakukan presentasi di depan kelas.

7) Sikap siswa dalam memperhatikan presentasi dan pendapat teman masih kurang.

8) Ketenangan kelas dalam pembelajaran masih kurang baik atau masih banyak yang ramai sendiri.

9) Keaktifan siswa secara individu pada siklus I dalam mengikuti kegiatan belajar mengajar dengan menggunakan model Problem Based Learning masih rendah, diperoleh skor 18 dari skor maksimal 30 dengan prosentase $60,00 \%$.

10)Hasil pengamatan terhadap aktivitas/performance guru pada siklus I diperoleh skor 23 atau 58,97\% dari skor maksimal 39 dengan kriteria pembelajaran "cukup" dalam menyampaikan pokok bahasan, tetapi awal pelajaran kurang dapat memotivasi siswa sehingga dalam proses pembelajaran keaktifan siswa masih kurang.

Hasil evaluasi pada siklus I diperoleh nilai tertinggi 7,60; nilai terendah 4,4; nilai rata-rata 6,74; siswa yang tuntas belajar sebanyak 9 siswa atau 45,00\%; dan siswa yang tidak tuntas belajar sebanyak 11 siswa atau 55,00\%; serta diperoleh ketuntasan belajar klasikal 45,00\%. Dari hasil siklus I, berarti dalam proses belajar belum berhasil atau belum memenuhi kriteria ketuntasan belajar secara klasikal. Oleh karena itu, perlu diadakan perbaikan tindakan yang akan dilakukan pada siklus II. 


\section{b. Siklus b}

Tabel 6 Keaktifan Siswa secara Individu Siklus II

\begin{tabular}{|c|c|c|c|c|}
\hline \multirow{2}{*}{ NO } & \multirow{2}{*}{ Keaktifan siswa } & \multicolumn{3}{|c|}{ Skor pengamatan } \\
\hline & & 1 & 2 & 3 \\
\hline 1 & Kehadiran siswa dalam mengikuti pelajaran & & & 3 \\
\hline 2 & $\begin{array}{l}\text { Siswa memperhatikan saat guru menjeaskan pokok } \\
\text { bahasan pelajaran }\end{array}$ & & & 3 \\
\hline 3 & Keaktifan siswa dalam mengikti pelajaran & & & 3 \\
\hline 4 & Kemampuan siswa dalam mengerjakan soal & & & 3 \\
\hline 5 & Kemampuan siswa dalam menanggapi masalah & & & 3 \\
\hline 6 & $\begin{array}{l}\text { Siswa menyelesaikan soal menggunakan lembar } \\
\text { kerja }\end{array}$ & & & 3 \\
\hline 7 & $\begin{array}{l}\text { Siswa berinteraksi satu sama lain (misalnya } \\
\text { bertanya,diskusi,dll. }\end{array}$ & & & 3 \\
\hline 8 & $\begin{array}{l}\text { Siswa berani bertanya kepada guru apabila menemui } \\
\text { kesulitan }\end{array}$ & & 2 & \\
\hline 9 & Semangat siswa dalam belajar & & & 3 \\
\hline \multirow[t]{6}{*}{10} & Ketenangan kelas & & & 3 \\
\hline & Jumlah & 0 & 2 & 27 \\
\hline & Total Skor & \multicolumn{3}{|c|}{29} \\
\hline & Skor Maksimal & \multicolumn{3}{|c|}{30} \\
\hline & Prosentase Skor (\%) & \multicolumn{3}{|c|}{$96.67 \%$} \\
\hline & Kriteria Penafsiran & \multicolumn{3}{|c|}{ Tinggi } \\
\hline
\end{tabular}

Penilaian:

1: Jika banyaknya siswa melakukan aktivitas $<45 \%$

2: Jika banyaknya siswa yang melakukan aktivitas $45 \%-75 \%$

3: Jika banyaknya siswa yan melakukan aktivitas $>75 \%$

Kriteria penafsiran:

$$
\begin{array}{ll}
>75 \% & =\text { Keaktifan tinggi } \\
65 \%-75 \% & =\text { Keaktifan sedang } \\
<65 \% & =\text { Keaktifan rendah }
\end{array}
$$


62 | Tarbawi : Jurnal Pendidikan Islam Vol. 17. No. 2. Juli - Desember 2020

Tabel 7 Observasi Siswa secara Kelompok Siklus II

\begin{tabular}{|c|c|c|c|c|c|c|c|c|c|c|c|c|c|c|c|c|c|c|c|c|c|c|c|c|c|c|c|}
\hline \multirow{2}{*}{ Kel. } & \multirow{2}{*}{ No } & \multirow{2}{*}{ Nama Siswa } & \multicolumn{4}{|c|}{ A } & \multicolumn{4}{|c|}{ B } & \multicolumn{4}{|c|}{ C } & \multicolumn{4}{|c|}{ D } & \multicolumn{3}{|c|}{$E$} & \multirow{2}{*}{$\mathrm{Jml}$} & \multirow{2}{*}{$\begin{array}{l}\text { Skor } \\
\text { Maks } \\
\end{array}$} & \multirow{2}{*}{ Skor } & \multirow{2}{*}{$\begin{array}{l}\text { Skor } \\
\text { Kel }\end{array}$} & \multirow{2}{*}{$\%$} & \multirow{2}{*}{ Ket } \\
\hline & & & 1 & 2 & 3 & 4 & 1 & 2 & 3 & 4 & 1 & 2 & 3 & 4 & 1 & 2 & 3 & 4 & 1 & 23 & 4 & & & & & & \\
\hline \multirow{6}{*}{1} & 1 & Sandi & & & & 4 & & & & 4 & & & & 4 & & & 3 & & & 3 & & 18 & 20 & 9.00 & \multirow{6}{*}{9.40} & $90 \%$ & $\begin{array}{c}\text { Baik } \\
\text { Sekali }\end{array}$ \\
\hline & 2 & Ahmad Dani & & & & 4 & & & & 4 & & & & 4 & & & 3 & & & & 4 & 19 & 20 & 9.50 & & $95 \%$ & $\begin{array}{c}\text { Baik } \\
\text { Sekali }\end{array}$ \\
\hline & 3 & Haikal & & & & 4 & & & & 4 & & & & 4 & & & 3 & 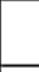 & & & 4 & 19 & 20 & 9.50 & & $95 \%$ & $\begin{array}{c}\text { Baik } \\
\text { Sekali }\end{array}$ \\
\hline & 4 & Moh. Ghony & & & & 4 & & & 3 & - & & & & 4 & & & & 4 & & & 4 & 19 & 20 & 9.50 & & $95 \%$ & $\begin{array}{c}\text { Baik } \\
\text { Sekali }\end{array}$ \\
\hline & 5 & $\begin{array}{l}\text { Ahmad } \\
\text { Zidan } \\
\end{array}$ & & & & 4 & & & & 4 & & & & 4 & & & 3 & & & & 4 & 19 & 20 & 9.50 & & $95 \%$ & $\begin{array}{c}\text { Baik } \\
\text { Sekali }\end{array}$ \\
\hline & \multicolumn{2}{|r|}{ Jumlah } & \multicolumn{4}{|c|}{ Jumlah } & \multicolumn{4}{|c|}{19} & & 20 & & & & 1 & & & & 19 & & 94 & 100 & 9.40 & & $94 \%$ & \\
\hline & 1 & Dinda Tri & & & & 4 & & & 3 & & & & & 4 & & & & 4 & & & 4 & 19 & 20 & 9.50 & & $95 \%$ & $\begin{array}{c}\text { Baik } \\
\text { Sekali }\end{array}$ \\
\hline & 2 & $\begin{array}{l}\text { Indira } \\
\text { Rahma } \\
\end{array}$ & & & 3 & & & & & 4 & & & & 4 & & & 3 & & & 3 & & 17 & 20 & 8.50 & & $85 \%$ & $\begin{array}{c}\text { Baik } \\
\text { Sekali }\end{array}$ \\
\hline 2 & 3 & $\begin{array}{l}\text { Sutan } \\
\text { Nafaras }\end{array}$ & & & & 4 & & & & 4 & & & 3 & & & & & 4 & & 3 & & 18 & 20 & 9.00 & 9.20 & $90 \%$ & $\begin{array}{c}\text { Baik } \\
\text { Sekali }\end{array}$ \\
\hline & 4 & Doniawan & & & & 4 & & & & 4 & & & & 4 & & & 3 & 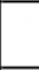 & & 3 & & 18 & 20 & 9.00 & & $90 \%$ & $\begin{array}{c}\text { Baik } \\
\text { Sekali }\end{array}$ \\
\hline & 5 & Moh. Kifli & & & & 4 & & & & 4 & & & & 4 & & & & 4 & & & 4 & 20 & 20 & 10.00 & & $100 \%$ & $\begin{array}{c}\text { Baik } \\
\text { Sekali }\end{array}$ \\
\hline & & Jumlah & & Jun & & & & 1. & & & & 19 & & & & 18 & & & & 17 & & 92 & 100 & 9.20 & & $92 \%$ & \\
\hline & 1 & Moh. Fajri & & & 3 & & & & 3 & & & & & 4 & & & & 4 & & 3 & & 17 & 20 & 8.50 & & $85 \%$ & $\begin{array}{c}\text { Baik } \\
\text { Sekali }\end{array}$ \\
\hline & 2 & Dika Bayu & & & & 4 & & & 3 & & & & & 4 & & & 3 & & & & 4 & 18 & 20 & 9.00 & & $90 \%$ & $\begin{array}{c}\text { Baik } \\
\text { Sekali }\end{array}$ \\
\hline 3 & 3 & Bayu Dian & & & & 4 & & & & 4 & & & & 4 & & & & 4 & & & 4 & 20 & 20 & 10.00 & 9.10 & $100 \%$ & $\begin{array}{c}\text { Baik } \\
\text { Sekali }\end{array}$ \\
\hline & 4 & Puja Juleita & & & & 4 & & & & 4 & & & & 4 & & & 3 & & & & 4 & 19 & 20 & 9.50 & & $95 \%$ & $\begin{array}{c}\text { Baik } \\
\text { Sekali } \\
\end{array}$ \\
\hline & 5 & Devi Aulia & & & 3 & & & & & 4 & & & 3 & & & & & 4 & & 3 & & 17 & 20 & 8.50 & & $85 \%$ & $\begin{array}{c}\text { Baik } \\
\text { Sekali } \\
\end{array}$ \\
\hline & & Jumlah & & Jun & & & & 1 & & & & 19 & & & & 18 & & & & 18 & & 91 & 100 & 9.10 & & $91 \%$ & \\
\hline & 1 & Farel & & & & 4 & & & & 4 & & & & 4 & & & 3 & & & & 4 & 19 & 20 & 9.50 & & $95 \%$ & $\begin{array}{c}\text { Baik } \\
\text { Sekali }\end{array}$ \\
\hline & 2 & Habib Jamal & & & 3 & & & & & 4 & & & & 4 & & & & 4 & & & 4 & 19 & 20 & 9.50 & & $95 \%$ & $\begin{array}{c}\text { Baik } \\
\text { Sekali }\end{array}$ \\
\hline 4 & 3 & Riska Eli & & & & 4 & & & & 4 & & & 3 & & & & & 4 & & & 4 & 19 & 20 & 9.50 & 9.50 & $95 \%$ & $\begin{array}{c}\text { Baik } \\
\text { Sekali }\end{array}$ \\
\hline & 4 & $\begin{array}{l}\text { Suci } \\
\text { Hardianti }\end{array}$ & & & & 4 & & & & 4 & & & & 4 & & & & 4 & & & 4 & 20 & 20 & 10.00 & & $100 \%$ & $\begin{array}{c}\text { Baik } \\
\text { Sekali } \\
\end{array}$ \\
\hline & 5 & Ririn Wulan & & & & 4 & & & 3 & & & & & 4 & & & & 4 & & 3 & & 18 & 20 & 9.00 & & $90 \%$ & $\begin{array}{c}\text { Baik } \\
\text { Sekali }\end{array}$ \\
\hline & & Jumlah & & 1 & & & & 1 & & & & 19 & & & & 19 & & & & 19 & & 95 & 100 & 9.50 & & $95 \%$ & \\
\hline & & Total & & 7 & & & & 7 & & & & 77 & & & & 71 & & & & 73 & & 372 & Baik S & kali & & & 20 \\
\hline & & cor Maksimal & & 8 & & & & 8 & & & & 80 & & & & 80 & & & & 80 & & 400 & Baik & & & & 0 \\
\hline & & $\begin{array}{l}\text { gkat Aktivitas } \\
\text { (\%) }\end{array}$ & & 95 & & & & 94 & & & & 96 & & & & 89 & & & & $91 \%$ & & $93.00 \%$ & Cukup & & & & 0 \\
\hline & & Kreiteria & & Tin & & & & Tin & & & & Ting & & & & Ting & & & & Tinggi & & Tinggi & Skor K & Terting & & & 10.00 \\
\hline & & & & t & & & & B & & & & C & & & & D & & & & E & & & Skor K & I Terend & & & 8.50 \\
\hline & & & & & & & & & & & & & & & & & & & & & & & Skor R & ta-rata : & & & 9.30 \\
\hline
\end{tabular}


Tabel 8 Hasil Keaktifan Siswa secara Kelompok Siklus II

\begin{tabular}{|c|c|l|c|c|c|}
\hline No & \multicolumn{1}{|c|}{ Aktivitas Siswa } & Skor & $\%$ & Ket \\
\hline 1 & A. & Memperhatikan penjelasan guru & 76 & $95 \%$ & Tinggi \\
\hline 2 & B. & Kerja sama dalam kelompok & 75 & $94 \%$ & Tinggi \\
\hline 3 & C. & Bertanya antar siswa dan guru & 77 & $96 \%$ & Tinggi \\
\hline 4 & D. & Keaktifan Menyelesaikan soal & 71 & $89 \%$ & Tinggi \\
\hline 5 & E. & Kemampuan presentasi siswa & 73 & $91 \%$ & Tinggi \\
\hline
\end{tabular}

Tabel 9 Pengamatan Kegiatan Guru Siklus II

\begin{tabular}{|c|c|c|c|c|c|}
\hline \multirow{2}{*}{ NO } & \multirow[b]{2}{*}{ Aspek yang dinilai } & \multicolumn{3}{|c|}{ SKOR } & \multirow{2}{*}{ Jml } \\
\hline & & 1 & 2 & 3 & \\
\hline \multirow[t]{4}{*}{1.} & Apersepsi & & & & \\
\hline & a.Menjelaskan tujuan pembelajaran & & & 3 & 3 \\
\hline & b. Menjelaskan pokok bahasan sesuai dengan model pembelajaran & & 2 & & 2 \\
\hline & c. Memotivasi siswa mengidentifikasi soal dan memecahkan masalah & & & 3 & 3 \\
\hline \multirow[t]{3}{*}{2} & Mengorganisasikan siswa untuk belajar & & & & \\
\hline & a.Membimbing siswa mengerjakan tugas dalam kelompok & & & 3 & 3 \\
\hline & b.Membimbing siswa dalam menggunakan lembar kerja & & & 3 & 3 \\
\hline \multirow[t]{3}{*}{3} & Membimbing siswa secara individu atau kelompok & & & & \\
\hline & a. Melakukan pengamatan tiap kelompok & & & 3 & 3 \\
\hline & b. Merekam kegiatan siswa & & & 3 & 3 \\
\hline \multirow[t]{5}{*}{4} & Mengembangkan hasil kerja siswa & & & & \\
\hline & a. Membimbing siswa membagi tugas dalam kelompok & & & 3 & 3 \\
\hline & b. Membantu siswa yang mengalami kesulitan & & & 3 & 3 \\
\hline & c. Membimbing siswa untuk melakukan presentase di depan kelas & & & 3 & 3 \\
\hline & d. Menganalisa dan menyimpulkan & & & 3 & 3 \\
\hline \multirow[t]{7}{*}{5} & Menganalisa dan mengevaluasi pemecahan & & & & \\
\hline & a. Membantu siswa memrikasa hasil kerja sesame siswa & & & 3 & 3 \\
\hline & b. Membantu siswa memeriksa prosedur pekerjaan siswa & & & 3 & 3 \\
\hline & Jumlah skor yang dicapai & \multicolumn{4}{|c|}{38} \\
\hline & Jumlah skor maksimal & \multicolumn{4}{|c|}{39} \\
\hline & Kinerja guru (\%) & \multicolumn{4}{|c|}{$97.44 \%$} \\
\hline & Kriteria & \multicolumn{4}{|c|}{ Baik } \\
\hline
\end{tabular}

Keterangan :

$$
1 \text { = Kurang }
$$$$
2 \text { = Cukup }
$$$$
3 \text { = Baik }
$$

Kreteria :

$$
\begin{aligned}
& 31-39=\text { Pembelajaran baik } \\
& 22-20=\text { Pembelajaran cukup baik } \\
& 13-21=\text { Pembelajaran kurang baik }
\end{aligned}
$$


64 | Tarbawi : Jurnal Pendidikan Islam Vol. 17. No. 己. Juli - Desember 2020

Tabel 10 Hasil Tes Kompetensi Siswa Siklus II

\begin{tabular}{|c|c|c|c|c|c|c|c|c|c|c|c|}
\hline \multirow{2}{*}{ No } & \multirow{2}{*}{ Nama Siswa } & \multicolumn{5}{|c|}{ Butir Soal } & \multirow{2}{*}{ Jml Skor } & \multirow{2}{*}{$\begin{array}{l}\text { Skor } \\
\text { Maks }\end{array}$} & \multirow{2}{*}{ Nilai } & \multirow{2}{*}{$\%$} & \multirow{2}{*}{ Kriteria } \\
\hline & & 1 & 2 & 3 & 4 & 5 & & & & & \\
\hline 1 & Sandi & 4 & 5 & 5 & 5 & 5 & 24 & 25 & 9.60 & $96.00 \%$ & Tuntas \\
\hline 2 & Ahmad Dani & 5 & 4 & 5 & 3 & 5 & 22 & 25 & 8.80 & $88.00 \%$ & Tuntas \\
\hline 3 & Haikal & 4 & 5 & 4 & 4 & 5 & 22 & 25 & 8.80 & $88.00 \%$ & Tuntas \\
\hline 4 & Moh. Ghony & 4 & 4 & 4 & 5 & 4 & 21 & 25 & 8.40 & $84.00 \%$ & Tuntas \\
\hline 5 & Ahmad Zidan & 4 & 4 & 5 & 4 & 4 & 21 & 25 & 8.40 & $84.00 \%$ & Tuntas \\
\hline 6 & Dinda Tri & 5 & 4 & 4 & 4 & 4 & 21 & 25 & 8.40 & $84.00 \%$ & Tuntas \\
\hline 7 & Indira Rahma & 4 & 4 & 5 & 4 & 5 & 22 & 25 & 8.80 & $88.00 \%$ & Tuntas \\
\hline 8 & Sutan Nafaras & 5 & 4 & 4 & 4 & 4 & 21 & 25 & 8.40 & $84.00 \%$ & Tuntas \\
\hline 9 & Doniawan & 4 & 4 & 4 & 4 & 3 & 19 & 25 & 7.60 & $76.00 \%$ & Tuntas \\
\hline 10 & Moh. Kifli & 4 & 4 & 4 & 4 & 4 & 20 & 25 & 8.00 & $80.00 \%$ & Tuntas \\
\hline 11 & Moh. Fajri & 5 & 4 & 4 & 4 & 4 & 21 & 25 & 8.40 & $84.00 \%$ & Tuntas \\
\hline 12 & Dika Bayu & 5 & 5 & 5 & 4 & 4 & 23 & 25 & 9.20 & $92.00 \%$ & Tuntas \\
\hline 13 & Bayu Dian & 5 & 4 & 4 & 5 & 5 & 23 & 25 & 9.20 & $92.00 \%$ & Tuntas \\
\hline 14 & Puja Juleita & 3 & 5 & 2 & 5 & 5 & 20 & 25 & 8.00 & $80.00 \%$ & Tuntas \\
\hline 15 & Devi Aulia & 5 & 5 & 4 & 4 & 4 & 22 & 25 & 8.80 & $88.00 \%$ & Tuntas \\
\hline 16 & Farel & 5 & 4 & 4 & 5 & 5 & 23 & 25 & 9.20 & $92.00 \%$ & Tuntas \\
\hline 17 & Habib Jamal & 5 & 4 & 3 & 4 & 4 & 20 & 25 & 8.00 & $80.00 \%$ & Tuntas \\
\hline 18 & Riska Eli & 4 & 5 & 4 & 5 & 5 & 23 & 25 & 9.20 & $92.00 \%$ & Tuntas \\
\hline 19 & Suci Hardianti & 4 & 5 & 4 & 4 & 5 & 22 & 25 & 8.80 & $88.00 \%$ & Tuntas \\
\hline 20 & Ririn Wulan & 4 & 5 & 4 & 5 & 4 & 22 & 25 & 8.80 & $88.00 \%$ & Tuntas \\
\hline Jumlah & & 4 & 5 & 5 & 5 & 5 & 24 & 25 & 9.60 & $96.00 \%$ & Tuntas \\
\hline \multicolumn{9}{|c|}{ Rata-rata } & 8.64 & $86.40 \%$ & \\
\hline \multicolumn{9}{|c|}{ Nilai Tertinggi } & 9.60 & & \\
\hline \multicolumn{9}{|c|}{ Nilai Terrendah } & 7.60 & & \\
\hline \multicolumn{9}{|c|}{ Jumlah siswa yang tuntas } & 20 & $100 \%$ & \\
\hline \multicolumn{9}{|c|}{ Jumlah siswa yang tidak tuntas } & 0 & $0 \%$ & \\
\hline \multicolumn{9}{|c|}{ Ketuntasan Klasikal } & $100 \%$ & (Tuntas) & \\
\hline
\end{tabular}

Setelah melakukan pengamatan atas tindakan pembelajaran, selanjutnya diadakan refleksi dari tindakan yang telah dilaksanakan. Dalam kegiatan pada siklus II didapat hasil refleksi sebagai berikut:

1) Pada saat diskusi peneliti/guru memantau kerja masing-masing kelompok, sudah maksimal dan bimbingan yang dilaksanakan guru terhadap kelompok sudah merata, sehingga beberapa kelompok dapat menyelesaikan soal dengan baik. Bimbingan individu sudah diperhatikan, sehingga seluruh siswa terlibat dalam penyelesaian masalah. 
2) Peneliti/guru dalam menumbuhkan motivasi belajar siswa agar dapat menumbuhkan minat siswa dalam proses model Problem Based Learning sudah optimal.

3) Perhatian siswa terhadap penjelasan guru sudah meningkat.

4) Dalam mengerjakan soal siswa sudah aktif.

5) Pada waktu kerja kelompok siswa sudah bisa berinteraksi dengan yang lain.

6) Siswa sudah tidak merasa malu untuk melakukan presentasi.

7) Sikap siswa dalam memperhatikan presentasi dan pendapat teman sudah membaik.

8) Ketenangan kelas dalam pembelajaran sudah baik.

Hasil siklus II dapat diketahui bahwa keaktifan siswa dapat dikategorikan tinggi, diperoleh skor 29 atau 96,67\% dari skor maksimal 30 dan telah memenuhi indikator keberhasilan yang telah ditetapkan. Dan kinerja/performance guru pada siklus II diperoleh skor 38 atau 97,44\% dari skor maksimal 39, dengan kategori baik. Dari hasil evaluasi siswa pada siklus II diperoleh nilai tertinggi 9,60; nilai terendah 7,6 ; dan nilai rata-rata 8,64. Siswa yang tuntas belajar sebanyak 20 atau 100\% (tuntas semua). Hal ini menunjukkan adanya peningkatan dibandingkan dengan siklus I, dengan demikian tidak perlu lagi siklus ke tiga.

\section{Pembahasan Perbandingan Hasil Penelitian 2 Siklus}

Berdasarkan penelitian siklus I dan II dapat dilihat peningkatan hasil belajar dan keaktifan siswa kelas IV SDN 020 Tanjung Selor dapat dilihat pada tabel berikut ini :

a) Peningkatan prestasi yang dicapai siswa siklus I dan II

Peningkatan nilai prestasi yang diperoleh siswa pada setiap siklus mengalami peningkatan. Peningkatan nilai prestasi belajar siswa diperoleh me-lalui hasil belajar siswa (tes kompetensi) pada setiap siklus. Kemampuan siswa dalam menjawab soal evaluasi pokok bahasan ibadah salat dengan nilai $=/>$ 7,5 mencapai sekurang-kurangnya $80 \%$ dari jumlah siswa.

Adapun rekapitulasi perbandingan prestasi belajar siswa pada siklus dapat dilihat pada tabel berikut:

Tabel 11 Hasil Belajar Siswa Perbandingan Siklus I dan Siklus II

\begin{tabular}{|c|l|c|c|c|}
\hline No & \multicolumn{1}{|c|}{ Nama Siswa } & Siklus I & Siklus II & Keterangan \\
\hline 1 & Sandi & 7.60 & 9.60 & Meningkat \\
\hline 2 & Ahmad Dani & 6.40 & 8.80 & Meningkat \\
\hline
\end{tabular}


66 | Tarbawi : Jurnal Pendidikan Islam Vol. 17. No. 2. Juli - Desember 2020

\begin{tabular}{|c|l|c|c|c|}
\hline 3 & Haikal & 7.60 & 8.80 & Meningkat \\
\hline 4 & Moh. Ghony & 6.80 & 8.40 & Meningkat \\
\hline 5 & Ahmad Zidan & 7.60 & 8.40 & Meningkat \\
\hline 6 & Dinda Tri & 5.60 & 8.40 & Meningkat \\
\hline 7 & Indira Rahma & 5.60 & 8.80 & Meningkat \\
\hline 8 & Sutan Nafaras & 7.60 & 8.40 & Meningkat \\
\hline 9 & Doniawan & 6.80 & 7.60 & Meningkat \\
\hline 10 & Moh. Kifli & 7.60 & 8.00 & Meningkat \\
\hline 11 & Moh. Fajri & 7.20 & 8.40 & Meningkat \\
\hline 12 & Dika Bayu & 7.60 & 9.20 & Meningkat \\
\hline 13 & Bayu Dian & 7.60 & 9.20 & Meningkat \\
\hline 14 & Puja Juleita & 5.60 & 8.00 & Meningkat \\
\hline 15 & Devi Aulia & 5.20 & 8.80 & Meningkat \\
\hline 16 & Farel & 7.60 & 9.20 & Meningkat \\
\hline 17 & Habib Jamal & 7.60 & 8.00 & Meningkat \\
\hline 18 & Riska Eli & 6.00 & 9.20 & Meningkat \\
\hline 19 & Suci Hardianti & 6.80 & 8.80 & Meningkat \\
\hline 20 & Ririn Wulan & 4.40 & 8.80 & Meningkat \\
\hline Rata-rata & 6.74 & 8.64 & \\
\hline Nilai tertinggi & 7.60 & 9.60 & \\
\hline Nilai terrendah & 4.40 & 7.60 & \\
\hline Jumlah siswa yang tuntas & 9 & 20 & \\
\hline Jumlah siswa tidak tuntas & 11 & 0 & \\
\hline Ketuntasan klasikal & $45.00 \%$ & $100 \%$ & \\
\hline & & & & \\
\hline
\end{tabular}

Hasil belajar siswa dalam setiap siklus mengalami peningkatan. Pada siklus I, prestasi belajar siswa yang dioperoleh dari tes kompetensi siswa, mencapai rata-rata $67.40 \%$, nilai tertinggi 7,60 dan terendah 4,40 terdapat 9 siswa yang telah mencapai KKM dan 11 siswa yang belum mencapai KKM yang ditetapkan sehingga mengakibatkan kurang optimalnya pencapaian indikator keberhasilan tindakan.

Adanya beberapa siswa yang belum mencapai kriteria ketuntasan minimal yang ditetapkan, disebabkan oleh beberapa faktor, seperti: 1) Peneliti/guru dalam menumbuhkan motivasi belajar siswa dalam proses model Problem Based Learning masih kurang optimal. 2) Perhatian siswa terhadap penjelasan guru masih rendah. 3) Dalam mengerjakan soal siswa masih kurang aktif. 4) Ketenangan kelas dalam pembelajaran masih kurang baik atau masih banyak yang ramai sendiri. 5) Keaktifan siswa secara individu pada siklus I dalam mengikuti kegiatan belajar mengajar dengan menggunakan model Problem Based Learning masih rendah. 
Pada siklus II, prestasi belajar siswa mengalami peningkatan dengan mencapai rata-rata $86.40 \%$, nilai tertinggi 9,60 dan terendah 7,60 terdapat 20 siswa yang telah mencapai KKM dan 0 siswa yang belum mencapai KKM. Berdasarkan observasi proses belajar siswa pada setiap siklus, mengalami peningkatan yang sangat baik.

Ada beberapa faktor yang mendorong terjadinya peningkatan hasil belajar siswa, diantaranya: 1) Peneliti/guru dalam menumbuhkan motivasi belajar siswa agar dapat menumbuhkan minat siswa dalam proses model Problem Based Learning sudah optimal. 2) Perhatian siswa terhadap penjelasan guru sudah meningkat. 3) Dalam mengerjakan soal siswa sudah aktif. 4) Ketenangan kelas dalam pembelajaran sudah baik. 5) Keaktifan siswa secara individu pada siklus II dalam mengikuti kegiatan belajar mengajar dengan menggunakan model Problem Based Learning sudah baik.

Hasil siklus II dapat diketahui bahwa dari hasil evaluasi siswa pada siklus II diperoleh nilai tertinggi 9,60; nilai terendah 7,6; dan nilai rata-rata 8,64. Siswa yang tuntas belajar sebanyak 20 atau 100\% ( tuntas semua ). Hal ini menunjukkan adanya peningkatan dibandingkan dengan siklus I, dengan demikian tidak perlu lagi siklus ke tiga karena sudah tercapainya indikator penelitian tindakan kelas yakni dengan nilai = I > 7,5 mencapai sekurang-kurangnya $80 \%$ dari jumlah siswa. . Dengan meningkatnya hasil belajar siswa pada setiap siklus maka penerapan model Problem Based Learning mampu meningkatkan hasil belajar siswa.

b) Keaktifan siswa secara individu siklus I dan II

Observasi proses belajar siswa dilakukan pada saat proses kegiatan belajar mengajar berlangsung. Dalam observasi keaktifan siswa secara individu terdapat 10 aspek yang menjadi penilaian, yaitu: 1) Kehadiran siswa dalam mengikuti pelajaran. 2) Siswa memperhatikan saat guru menjeaskan pokok bahasan pelajaran. 3) Keaktifan siswa dalam mengikti pelajaran. 4) Kemampuan siswa dalam mengerjakan soal. 5) Kemampuan siswa dalam menanggapi masalah. 6 Siswa menyelesaikan soal menggunakan lembar kerja. 7) Siswa berinteraksi satu sama lain (misalnya bertanya, diskusi, dll. 8) Siswa berani bertanya kepada guru apabila menemui kesulitan. 9) Semangat siswa dalam belajar. 10) Ketenangan kelas. Indikator keberhasilan keaktifan siswa oleh observer bila mencapai minimal 60\%-75\% kreteria sedang.

Hasil perbandingan observasi aktivitas siswa pada siklus I dan II dapat dilihat dari tabel berikut ini. 
Tabel 12 Keaktifan Siswa Secara Individu Siklus I dan Siklus II

\begin{tabular}{|c|c|c|c|c|}
\hline NO & Keaktifan Siswa & Siklus I & Siklus II & Ket. \\
\hline 1 & Kehadiran siswa dalam mengikuti pelajaran & 3 & 3 & Sama \\
\hline 2 & $\begin{array}{l}\text { Siswa memperhatikan saat guru menjeaskan } \\
\text { pokok bahasan pelajaran }\end{array}$ & 2 & 3 & Meningkat \\
\hline 3 & Keaktifan siswa dalam mengikti pelajaran & 2 & 3 & Meningkat \\
\hline 4 & Kemampuan siswa dalam mengerjakan soal & 2 & 3 & Meningkat \\
\hline 5 & $\begin{array}{l}\text { Kemampuan siswa dalam menanggapi } \\
\text { masalah }\end{array}$ & 2 & 3 & Meningkat \\
\hline 6 & $\begin{array}{l}\text { Siswa menyelesaikan soal menggunakan } \\
\text { lembar kerja }\end{array}$ & 1 & 3 & Meningkat \\
\hline 7 & $\begin{array}{l}\text { Siswa berinteraksi satu sama lain (misalnya } \\
\text { bertanya,diskusi,dll. }\end{array}$ & 1 & 3 & Meningkat \\
\hline 8 & $\begin{array}{l}\text { Siswa berani bertanya kepada guru apabila } \\
\text { menemui kesulitan }\end{array}$ & 2 & 2 & Sama \\
\hline 9 & Semangat siswa dalam belajar & 2 & 3 & Meningkat \\
\hline 10 & Ketenangan kelas & 2 & 3 & Meningkat \\
\hline & Total Skor & 18 & 29 & Meningkat \\
\hline & Skor Maksimal & 30 & 30 & \\
\hline & Prosentase Skor (\%) & $60.00 \%$ & $96.67 \%$ & Meningkat \\
\hline & Kriteria Penafsiran & Rendah & Tinggi & Meningkat \\
\hline
\end{tabular}

Penilaian 1: Jika banyaknya siswa melakukan aktivitas $<45 \%$

2: Jika banyaknya siswa yang melakukan aktivitas $45 \%-75 \%$

3: Jika banyaknya siswa yan melakukan aktivitas $>75 \%$

Kriteria penafsiran: $>75 \%=$ Keaktifan tinggi

$$
\begin{array}{ll}
65 \%-75 \% & =\text { Keaktifan sedang } \\
<65 \% & =\text { Keaktifan rendah }
\end{array}
$$

Dari table diatas, terlihat jelas perubahan sekaligus peningkatan dari siklus I dan siklus II baik dari total skor, presentase dan kreteria penafsirannya. Peningkatan keaktifan siswa secara individu siklus I dengan total skor 18 dan siklus II 29, prosentase skor siklus I 60\% dan siklus II $96.6 \%$, kreteria penafsiran siklus I rendah dan siklus II tinggi artinya terjadi peningkatan dari siklus I ke siklus II keaktifan siswa belajar pendidikan agama Islam (PAI) pokok bahasan ibadah salat dengan menerapkan model Problem Based Learning

c) Keaktifan siswa secara kelompok siklus I dan II

Observasi keaktifan siswa secara kelompok Siklus I dan Siklus II da-lam proses belajar siswa dilakukan pada saat proses kegiatan belajar mengajar berlangsung. Dalam observasi keaktifan siswa secara kelompok Siklus I dan Siklus II terdapat 5 
aspek yang menjadi penilaian. Hasil perbandingan observasi aktivitas siswa pada siklus I dan II dapat dilihat dari table berikut ini.

Tabel 13 Keaktifan Siswa Secara Kelompok Siklus I dan Siklus II

\begin{tabular}{|c|c|l|c|c|l|}
\hline No & \multicolumn{2}{|c|}{ Aktifitas Siswa } & $\begin{array}{c}\text { Siklus } \\
\text { I }\end{array}$ & $\begin{array}{c}\text { Siklus } \\
\text { II }\end{array}$ & Keterangan \\
\hline 1 & A. & $\begin{array}{l}\text { Memperhatikan penjelasan } \\
\text { guru }\end{array}$ & $59 \%$ & $95 \%$ & Meningkat \\
\hline 2 & B. & Kerja sama dalam kelompok & $63 \%$ & $94 \%$ & Meningkat \\
\hline 3 & C. & Bertanya antar siswa dan guru & $63 \%$ & $96 \%$ & Meningkat \\
\hline 4 & D. & Keaktifan Menyelesaikan soal & $60 \%$ & $89 \%$ & Meningkat \\
\hline 5 & E. & Kemampuan presentasi siswa & $60 \%$ & $91 \%$ & Meningkat \\
\hline
\end{tabular}

Dari table diatas, terlihat jelas perubahan sekaligus peningkatan dari siklus I dan siklus II aktifitas siswa dalam memperhatikan guru siklus | 59\% siklus II 95 \%, kerja sama dalam kelompok siklus I 63\% siklus II 94\%, bertanya antar siswa dan guru siklus I 63\% siklus II 96\%, keaktifan menyelesaikan soal siklus I 60\% siklus II 89\%, kemampuan presentase siswa siklus I 60\% siklus II 91 \%. Keaktifan siswa dalam kelompok terjadi peningkatan dari siklus I ke siklus II dalam belajar pendidikan agama Islam (PAI) pokok bahasan ibadah salat dengan menerapkan model Problem Based

\section{Learning}

d). Kinerja guru siklus I dan II

Tabel14 Kinerja Siklus I dan II

\begin{tabular}{|c|c|c|c|}
\hline NO & Aspek yang dinilai & Siklus I & Siklus II \\
\hline \multirow[t]{4}{*}{1.} & Apersepsi & & \\
\hline & Menjelaskan tujuan pembelajaran & 3 & 3 \\
\hline & $\begin{array}{l}\text { Menjelaskan pokok bahasan sesuai dengan model } \\
\text { pembelajaran }\end{array}$ & 2 & 2 \\
\hline & $\begin{array}{l}\text { Memotivasi siswa mengidentifikasi soal dan memecahkan } \\
\text { masalah }\end{array}$ & 1 & 3 \\
\hline \multirow[t]{3}{*}{2} & Mengorganisasikan siswa untuk belajar & & \\
\hline & a. Membimbing siswa mengerjakan tugas dalam kelompok & 2 & 3 \\
\hline & b.Membimbing siswa dalam menggunakan lembar kerja & 2 & 3 \\
\hline \multirow[t]{3}{*}{3} & Membimbing siswa secara individu atau kelompok & & \\
\hline & a. Melakukan pengamatan tiap kelompok & 2 & 3 \\
\hline & 1) Merekam kegiatan siswa & 1 & 3 \\
\hline \multirow[t]{5}{*}{4} & Mengembangkan hasil kerja siswa & & \\
\hline & a. Membimbing siswa membagi tugas dalam kelompok & 2 & 3 \\
\hline & b. Membantu siswa yang mengalami kesulitan & 2 & 3 \\
\hline & $\begin{array}{l}\text { c. Membimbing siswa untuk melakukan presentase di depan } \\
\text { kelas }\end{array}$ & 1 & 3 \\
\hline & d. Menganalisa dan menyimpulkan & 2 & 3 \\
\hline
\end{tabular}


70 | Tarbawi : Jurnal Pendidikan Islam Vol. 17. No. 2. Juli - Desember 2020

\begin{tabular}{|c|l|c|c|}
\hline 5 & Menganalisa dan mengevaluasi pemecahan & & \\
\cline { 2 - 4 } & a. Membantu siswa memrikasa hasil kerja sesama siswa & 2 & 3 \\
\cline { 2 - 4 } & b. Membantu siswa memeriksa prosedur pekerjaan siswa & 1 & 3 \\
\hline \multirow{2}{*}{ Jumlah skor yang dicapai } & 23 & 38 \\
\hline & Jumlah skor maksimal & 39 & 39 \\
\hline Kinerja guru (\%) & $58.97 \%$ & $97.44 \%$ \\
\hline Kriteria & Cukup & Baik \\
\hline
\end{tabular}

Keterangan:

$1=$ Kurang

2 = Cukup

$3=$ Baik
Kreteria :

$31-39=$ Pembelajaran baik

$22-30=$ Pembelajaran cukup

$13-21=$ Pembelajaran kurang

Berdasarkan analisis data, aktivitas guru selama pembelajaran telah melaksanakan langah-langkah metode pemberian tugas belajar dan resitasi dengan baik. Hal ini terlihat dari aktivitas guru yang muncul di antaranya aktivitas membimbing dan mengamati siswa dalam mengerjakan kegiatan LKS/menemukan konsep, menjelaskan/ melatih menggunakan alat, memberi umpan balik/ evaluasi/ tanya jawab, prosentase peningkatan dari siklus 1, $58.97 \%$ ke siklus II, $97.44 \%$ menunjukkan peningkatan dengan kreteria baik. Adapun indikator yang ingin dicapai keaktifan/kinerja peneliti/guru dalam melaksanakan pembelajaran di dalam kelas minimal dengan skor antara $65 \%$ - $75 \%$ dengan kreteria sedang.

Tabel 15 Komulatif perbandingan siklus I dan siklus II

\begin{tabular}{|c|l|c|c|}
\hline \multicolumn{4}{|c|}{ TABEL KOMULATIF PERBANDINGAN SIKLUS I DAN SIKLUS II } \\
\hline No & \multicolumn{1}{|c|}{ Indikator } & Siklus I & Siklus II \\
\hline 1 & Keaktifan siswa & $60 \%$ & $97 \%$ \\
\hline 2 & Keaktifan dalam kelompok & $61 \%$ & $93 \%$ \\
\hline 3 & Nilai rata-rata siswa & $67 \%$ & $86 \%$ \\
\hline 4 & Siswa tuntas & $45 \%$ & $100 \%$ \\
\hline 5 & Siswa tidak tuntas & $55 \%$ & $0 \%$ \\
\hline 6 & Ketuntasan klasikal & $45 \%$ & $100 \%$ \\
\hline 7 & Kinerja Guru & $59 \%$ & $97 \%$ \\
\hline 8 & Minat Siswa & \multicolumn{2}{|c|}{$82.50 \%$} \\
\hline
\end{tabular}

\section{SIMPULAN}

Setelah dilakukan análisis data dari hasil penelitian tindakan dan pembahasan, diperoleh kesimpulan bahwa model problem based learning yang telah dilaksanakan 
pada siswa kelas IV SDN 020 Tanjung Selor, tahun pelajaran 2017/2018, diperoleh kesimpulan sebagai berikut:

1. Ada peningkatan prestasi belajar Pendidikan Agama Islam (PAI) siswa setelah mengikuti model problem based learning, hal ini ditunjukkan dari hasil evaluasi pada siklus II (meningkat) dan sudah sesuai dengan indikator yang telah ditetapkan, dibandingkan dengan hasil evaluasi pada siklus I.

2. Ada peningkatan aktivitas siswa dalam mengikuti model problem based learning, hal ini ditunjukkan aktivitas siswa pada siklus II lebih baik (meningkat) dibandingkan dengan aktivitas siswa pada siklus I.

3. Ada peningkatan kinerja/performance guru dalam pelaksanaan model problem based learning. Hal ini ditunjukkan dengan adanya peningkatan kinerja/performance guru pada siklus II lebih baik dibandingkan dengan siklus I.

4. Respon siswa terhadap pelaksanaan model problem based learning, menunjukkan respon yang sangat baik.

\section{DAFTAR PUSTAKA}

Azwar, Saifuddin. 2010. Metode Penelitian. Yogyakarta: Pustaka Pelajar

Amir, T. 2009. Inovasi Pendidikan melalui Problem Based Learning: Bagaimana Pendidik memberdayakan Pembelajar di Era Pengetahuan. Jakarta: Kencana Prenada Media Group.

Anonim. "Pengertian dan Langkah Model Pembelajaran Problem Based Learning." http://www.infoduniapendidikan.com/2015/06/pengertian-dan-langkah-modelpembelajaran-problem-based-learning.html (diakses tanggal 6 Juni 2020)

Badudu, J.S. 1988. Kamus Besar Bahasa Indonesia. Jakarta: Gramedia

Budiningsih, C. Asri. 2005. Belajar dan Pembelajaran. Jakarta: PT Rineka Cipta.

Direktorat Jenderal Pendidikan Dasar dan Menengah Kementerian Pendidikan dan Kebudayaan. 2017. Model-Model Pembelajaran. Jakarta: Direktorat Pembinaan Sekolah Menengah Atas.

Darmadi. 2017. Pengembangan Model dan Metode Pembelajaran dalam Dinamika Belajar Siswa. Jogjakarta: Deepublish

Fathoni, Abdurrahman. 2006. Metodologi penelitian dan Teknik penyusunan Skripsi. Jakarta: PT. Rineka Cipta 
72 | Tarbawi : Jurnal Pendidikan Islam Vol. 17. No. 2. Juli - Desember 2020

Ikhsanudin, Eka. "Pembelajaran Problem Based Learning." http://www.ekaikhsanudin.net/2014/12/pembelajaran-problem-basedlearning.html, (diakses tanggal 6 Juni 2020)

Kemendikbud RI. "Undang-Undang Nomor 20 Tahun 2003 tentang Sistem Pendidikan Nasional." http://simkeu.kemdikbud.go.id/index.php/peraturan1/8-uu-undangundang/12-uu-no-20-tahun-2003-tentang-sistem-pendidikan-nasional (diakses tanggal 6 Juni 2020)

Neo, K.W., Ehyn, Y. K., \& Megan. 2002. Authentic Problem Based Learnig: Rewriting Business Education. Singapore: Prentice Hall

Sugiyono. 2017. Metode Penelitian Kuantitatif, Kuantitatif, dan R\&D. Bandung: CV Alfabeta. 